\title{
The perinatal period: A literature review from the biopsychosocial perspective
}

\author{
Melissa Buultjens ${ }^{1}$, Gregory Murphy ${ }^{1}$, Priscilla Robinson ${ }^{1}$, J eannette Milgrom ${ }^{2}$ \\ 1. School of Public Health and Human Biosciences, La Trobe University, Melbourne, Australia. 2. Clinical and Health \\ Psychology and Parent-Infant Research Institute, Austin Health, Melbourne, Australia.
}

Correspondence: Melissa Buultjens. Address: School of Public Health and Human Biosciences, La Trobe University, Melbourne 3086, Australia. Email: M.Buultjens@latrobe.edu.au

Received: January 22, 2013

Accepted: May 15, 2013

Online Published: May 22, 2013

DOI : $10.5430 /$ cns.v1n3p19

URL: http://dx.doi.org/10.5430/cns.v1n3p19

\begin{abstract}
This review paper presents research findings relating to physical, biological, social and psychological factors as they influence maternal and child health across the perinatal period. Taking a public health perspective, the paper also identifies best opportunities for service development to improve population health. Important gaps in our research knowledge about optimal maternal and child health are identified. The review concludes by highlighting the area of social support as a highly recommended priority for service development within maternal and child health.
\end{abstract}

\section{Key words}

Perinatal, Health promotion, Biopsychosocial, Public health nursing, Multidisciplinary

\section{I ntroduction}

In Western developed nations, studies from medical, behavioural and social sciences have led to great advances in our understanding of, and success in minimising, maternal and infant mortality and morbidity. The principles of public health provide a useful context for investigating maternal and child health throughout the perinatal period. Public health is often viewed as having a focus on the health of the population of a specific country or community ${ }^{[1]}$. An Australian definition of public health as formed by the health ministers attending the National Public Health Partnership (NPHP) in 1998 was established as "the organised response by society to protect and promote health and to prevent illness, injury and disability" ${ }^{[2]}$. Public Health is thought to involve the study of the morbidity, mortality and the cause and course of disease, at a population rather than individual level. Further, Public Health is concerned with examining factors that cause health inequalities ${ }^{[3]}$.

Having a baby is a significant transitional life event that can bring about various health and social disruptions that entail and are influenced by environmental, psychological, biological, sociological and organisational elements. In developed Western nations such as Australia, almost $90 \%$ of adults become parents, suggesting that the perinatal period and associated services have the potential to shape population health ${ }^{[4]}$, being a primary contributor to a healthy nation. In order to direct health promotion optimally and design evidence-based interventions and maternity services across the perinatal period, it is important to identify protective factors, recognise contexts that create risk and identify gaps in current research. 


\section{Biopsychosocial model of health}

The biopsychosocial model first gained attention in 1977 when it was presented to physicians as an alternative to the traditional biomedical model ${ }^{[5]}$. While recognising the advances in medicine that resulted from the application of the biomedical model, Engel ${ }^{[5]}$ challenged the biomedical model as it did not fully explain illness and disease. For example, the biomedical model failed to sufficiently explain the origin and progression of mental illness. Nor did it describe why individuals with the same illness would often respond differently from one another. The biopsychosocial model sought to acknowledge the patient in the larger context - as part of a complex biosphere - where the patient's internal schema were connected in a mutually influential interaction with dynamics and influences external to the patient.

The biopsychosocial model (which has been adopted by the World Health Organization (WHO) ${ }^{[6]}$ ) is helpful in understanding the health-related experience of a woman during the perinatal period. Using the International Classification of Functioning, Disability and Health (ICF) framework, a suitably broad range of variables impacting on maternal and child health throughout the perinatal period can be examined. This paper reports on results from key studies across the continuum of influencing factors - biological (including physical symptomology), psychological and social. This multifactorial approach was applied to review influencing and modifiable factors in the perinatal period to inform perinatal health professionals and policy-makers alike, as well as stimulate future research.

\section{Multidimensional challenges, risk factors and implications associated with the perinatal period}

While obstetric safety is a strength of Western medicine, there are disparities on other important indicators of perinatal health and wellbeing such as morbidity. These can include high rates of obstetric interventions, including caesarean section ${ }^{[7]}$, low breastfeeding rates ${ }^{[8,9]}$ and an increase in perinatal depression ${ }^{[10,11]}$. As a biopsychosocial process ${ }^{[12]}$, the perinatal period involves complex issues and different aspects that may be closely intertwined; for example, social factors such as level or type of support available may impact on the experience of pain and the perceived ability to recover from physical consequences of birth. The awareness of risk and protective factors can inform health professionals' decision making, provide families with timely access to appropriate services and facilitate public health, health-promoting initiatives. The following review examines the physical, biological, social, and psychological factors associated with health in pregnancy, childbirth and the postnatal period.

\subsection{Physical factors associated with perinatal health}

Transition theory posits that physical factors influence the attainment of healthy transition outcomes ${ }^{[13]}$. Pregnancy and childbirth can affect women's health, with many self reported physical morbidities being identified in the first year of parenthood ${ }^{[14]}$. It is for this reason that we review the physical constructs associated with the perinatal period to provide evidence of clinical practice outcomes, as well as potentially modifiable factors.

A recent WHO survey concluded that to improve maternal and perinatal outcomes, caesarean section should be performed only when medically indicated ${ }^{[15]}$. Caesarean birth is associated with increasing rates of severe maternal morbidity ${ }^{[16]}$, including sepsis, thromboembolic events, anaesthetic complications ${ }^{[17,18]}$ and hospital readmission ${ }^{[19]}$, often associated with uterine infection, obstetrical surgical wound complications, and cardiopulmonary and thromboembolic conditions ${ }^{[20]}$. In particular, a large population-based study found a nearly five-fold increased risk of acquiring a postpartum infection (bloodstream infection, urinary tract infection, or wound infection) after caesarean section compared to vaginal birth ${ }^{[21]}$. Qualitative commentary further reports a range of negative physical health outcomes, including pain and reduced mobility, vaginal bleeding and urinary incontinence ${ }^{[22]}$. Avoidance of pain during labour has been cited as a reason for elective caesarean delivery ${ }^{[23]}$. Given this, childbirth-specific anxiety during pregnancy should receive consideration, particularly in antenatal education and preparatory classes. Future research could evaluate specific interventions aimed at the reduction of childbirth-specific anxiety with regard to confidence building for women 
concerning their own intuitive physical capabilities during labor and strengthening their experience of control and self-efficacy.

Whilst caesarean section can result in these negative outcomes, trauma to the pelvic floor during childbirth can also result in serious pelvic floor morbidity, including damage to anatomic structures and nerves ${ }^{[24]}$. Investigating the influence of caesarean section compared with spontaneous vaginal delivery during a first delivery and the implications for pelvic floor surgery in later life, Uma, Libby \& Murphy ${ }^{[24]}$ illustrated an association between caesarean section delivery and a reduced risk of pelvic floor surgery. However Uma's study did not demonstrate an increased risk of pelvic floor surgery later in life following forceps delivery compared with vaginal delivery, nor was high infant birth weight $>4.0 \mathrm{~kg}$ identified as reliable risk factors. Episiotomy and prolonged labour ( $>12$ hours) were found to be associated risk factors but were of borderline significance ${ }^{[24]}$. This highlights the challenge for health educators and physicians to provide women with reliable, replicated evidence-based information, of not only intrapartum care, but also potential long term health outcomes for women. Identifying women at high-risk for delivery-related pelvic floor trauma should be a priority. Further there is no evidence whether avoidance of potential intrapartum pelvic floor trauma is worth the risk, cost, and effort of conducting an elective caesarean section.

While the immediate concerns of perinatal care are with potentially life-threatening or serious morbidity, many problems are long-term and, even when non life-threatening, can have a significant impact on some aspects of the lives and well-being of women and their families ${ }^{[25,26]}$. It is also understood that the health of women after childbirth may be directly correlated to the health of their children ${ }^{[27]}$. For example, a mother's negative view of her own health can have a negative impact on her infant care behaviours ${ }^{[28]}$. Cheng ${ }^{[29]}$ conducted an integrated review of research on the general health status and prevalence of common physical health conditions of women following childbirth, identifying numerous health disparities. Almost all of the women in the reviewed studies encountered $>1$ physical health condition at some point during their first year postpartum.

The changes in a woman's body associated with pregnancy, birth and puerperium can affect maternal functional health ${ }^{[30]}$. Several epidemiological studies reveal physical problems consistent with those commonly found in short-term studies, including dyspareunia, urinary and faecal incontinence, perineal pain and haemorrhoids ${ }^{[31-33]}$. According to Borders' review of postpartum health ${ }^{[33]}$, perineal pain has been reported to be present in $31 \%$ of the literature reviewed, sexual problems / dyspareunia in $11 \%$ - 49\%, urinary stress incontinence in $3 \%-7 \%$, backache in $8 \%-64 \%$ and extreme tiredness in 6\% - 48\%; many of these symptoms and complaints persisted long-term ( $>6$ months postpartum). Representing a major source of personal and social embarrassment, these problems have been expressed as hidden morbidities ${ }^{[34]}$. While these statistics illustrate high rates of poor physical health postpartum, for many physical conditions such as tiredness and backaches, postpartum women do not seek assistance from health care professionals ${ }^{[35]}$. Using the example of pelvic floor muscle training, evidence clearly shows that high adherence to a strength-training protocol and close follow-up can prevent and treat this condition ${ }^{[36]}$, however the optimal dosage for effective PFMT is still not known and further research is required using high-quality randomised controlled trials.

In an early study conducted by McCourt \& Page ${ }^{[37]}$ findings showed that around $70 \%$ reported perineal or caesarean wound pain at two weeks and for a third of women, this was classified as severe. Over $20 \%$ of women reported problems of leaking urine at two weeks, and at 12 weeks this proportion had increased rather than decreased to around $30 \%$. Finally over half of the women reported suffering backaches two weeks postnatally, and at 12 weeks this proportion had increased rather than declined. Postpartum follow-up studies have shown that about $8-20 \%$ of women still have persistent non-specific lumbopelvic pains $2-3$ years after delivery ${ }^{[38,39]}$. Again, such health disparities can interfere with daily activities and restrict participation in leisure interests previously undertaken. Awareness of potential health problems may enable health care professionals to provide appropriate and timely services to help prevent postpartum ill-health, as well as reducing severity and prevalance ${ }^{[40]}$. 
Postpartum physical symptoms have the potential to decrease a woman's quality of life, particularly given the significant association between physical symptoms and emotional problems ${ }^{[41]}$. Chein, Tai ${ }^{[42]}$ found that at least one of the 18 physical symptoms surveyed was reported by $97.6 \%$ of women at one month and $91.6 \%$ at one year after delivery. Again, this finding is consistent with previous reports of a high prevalance of physical morbidity in women after childbirth ${ }^{\text {[43-45] }}$. Williams, Herron-Marx \& Knibb ${ }^{[45]}$ reported that $87 \%$ of women complained of at least one index of morbidity at 12 months postpartum. While Australian mortality rates are often distingished as the main indicator of a quality maternity service, there is emerging literature that suggests that these less severe health problems are highly prevelant and just as meaningful to childbearing women ${ }^{[46,47]}$.

Peer-reviewed literature indicates that there is a significant association between postpartum physical symptoms and emotional problems, which interfere with a woman's adaption to parenthood. A postal survey seeking the prevalence of physical and emotional health problems of women in Victoria, Australia found that $94 \%$ (of the 1336 respondents) reported one or more health problems in the first six months postnatal. Further, of these women, almost $17 \%$ scored as depressed on the Edinburgh Postnatal Depression Scale ${ }^{[41]}$. Maternal depressive symptomology was significantly associated with tiredness, urinary incontinence, back pain, sexual problems, and more colds and illnesses than usual. Following that earlier study, the same researchers ${ }^{[48]}$ followed a subsample of women $(n=204)$ for six weeks by telephone interview. Results similarly showed that maternal depression measured at the time of the initial survey was associated with factors such as current urinary incontinence, tiredness, and having more colds and illnesses than usual. Women with urinary incontinence were more than twice as likely as continent women to be depressed. Given the vast health complications that can affect maternal functioning, it should be common practice for obstetric caregivers to promptly refer women to other health care specialists (e.g. psychologist, physiotherapist).

Similarly, a Swedish study found that depressive symptoms were three times more prevalent in women having lumbopelvic pain than in those without ${ }^{[49]}$. In a more recent study, Webb and colleagues ${ }^{[50]}$ found that the presence, severity and cumulative morbidity of physical problems were again positively associated with depressive symptomatology. For example, there were statistically significant relationships, indicating a higher probability of depressive symptomatology with conditions such as fatigue, backache, and vaginal pain or dyspareunia.The respective proportions were fatigue, $27.9 \%$, backache, $29.3 \%$, vaginal pain or dyspareunia, $43.6 \%$. These studies indicate that physical problems are reliably related to women's functional impairment and emotional health. Promoting models of care that integrate postnatal physical and emotional assessment has been identified by the World Health Organisation as a priority area ${ }^{[51]}$. In Australia, Clinical Practice Guidlines endorsed by the National Health and Medical Research Council on the management of perinatal depression promote assessment of maternal mental health across the perinatal period using the Edinburgh Postnatal Depression Scale, and provide guidance to primary care practitioners regarding ongoing management of maternal mental health problems ${ }^{[52]}$, however, assessment of maternal physical health is not mentioned in these guidelines. It seems that early intervention to promote maternal mental health should incorporate assessment and intervention to address common maternal physical health problems.

As noted, chidbirth has a major impact on a woman's physical health and as examined, the extent of postnatal morbidity is extensive. Postpartum quality of life can be influenced by obstetric factors, such as mode of delivery, while physical symptoms of poor health can interfere with a woman's adaption to motherhood. The birth of a baby signals major changes in a woman's life, and comprehensive services and assessment is required by healthcare systems to optimally prepare women for the immediate maternal consequences. To move this field of research forward what is now needed are controlled experiemental studies (with economic analyses included) of particular manulised interventions aimed at improving expectant mothers resilience.

\subsection{Biological factors associated with perinatal health}

For the purposes of this review, 'biological properties' are concerned with factors such as hormonal influences and maternal nutrition - the latter which can be modified to foster healthy outcomes. There is evidence concerning the 
contribution of biological etiological factors to the development of mood disorders. Biological factors that are known to contribute to the pathophysiology of maternal depression include hormonal influences ${ }^{[53]}$ and neurotransmitter function ${ }^{[54]}$. Furthermore, studies indicate that some women are particularly sensitive to hormonal fluctuations, thus increasing their susceptibility to psychological stressing agents that are triggered by environmental and physiological factors ${ }^{[55]}$. Preterm birth has been identified as one potential outcome of fetal exposure to stress during pregnancy, and is further associated with a host of negative consequences for the fetus and subsequent development ${ }^{[56]}$. Complementary therapeutic interventions (e.g. yoga) may be a useful addition to traditional antenatal education classes, however these need to be amenable to evidence-based evaluation in a research environment to determine their usefulness.

In examining the association between psychobiological stress reactivity during healthy pregnancy and depressive symptoms in the early puerperium, statistical analyses revealed that the probable case group (Edinburgh Postnatal Depression Scale > 9) showed signifciantly higher cortisol responses to the stress test compared with the probable non case group (EPDS $\leqslant 9$ ) ${ }^{[57]}$. However, whilst changes in certain hormonal axes may contribute to depressive mood changes in some women following childbirth, evidence is still limited regarding the etiological role of such hormones ${ }^{[58]}$ and further research is required to clarify the mechanisms involved.

One biological factor given increasing consideration is nutrition. Childbearing women are particularly vulnerable to the adverse effects of poor nutrition on mood ${ }^{[59]}$. Pregnancy and lactation ${ }^{[60]}$ are major nutritional stressors on the body ${ }^{[61]}$. In combination, the depletion of nutrient reserves throughout pregnancy and a lack of recovery postpartum may increase a woman's risk of depression ${ }^{[62,63]}$. On an individual level, antenatal education towards dietry modification can not only enhance nutritional uptake and hence improve maternal mental health outcomes, but at the population level it has the potential to positively impact public health. Which and how much food is ingested can have long-term effects on both mother and infant ${ }^{[64]}$, however very little research has investigated what specific nutrition counseling achieves the best outcomes (e.g. compliance to recommended diet).

\subsection{Social factors associated with perinatal health}

There are many social influences, including social network factors and social demographics, which can shape an individual's experience of the perinatal period. Several international reports have identified social inequality as a major determinant of inferior health outcomes ${ }^{[65]}$. Within the maternal and child health domain, there is strong evidence to suggest an association between low-birth-weight and small-for-gestational-age infants, and social complexities and deprivation ${ }^{[66-68]}$. Examples of health-related social disparity in the community include poorer general health outcomes for blue-collar workers compared with white-collar workers. Within the field of maternal and child health, for example, Gissler and colleagues found that mothers who were blue-collar workers had had a $14 \%$ higher risk for pre-term births, and a $25 \%$ higher risk for low-birth-weight infants. Consistent with these results a qualitative study of single parents ${ }^{[69]}$ found a higher incidence of pregnancy-related and birth-related mental health problems such as depression.

There are also widely reported associations between maternal distress in pregnancy and low birth weight ${ }^{[70]}$. Researchers believe there are two potential explanations. The first is that psychosocial factors such as stress or lack of social support impact on birth outcomes via neuroendocrine, immune or vascular mechanisms ${ }^{[71]}$. The second explanation involves the impact of health-related behaviors that are known to be linked with increased risks such as smoking, maternal nutrition, infection and substance use ${ }^{[72]}$. With knowledge of these behavioural and social determinants, there is opportunity to target preventative resources, and by aiming at reducing social and behavioural disadvantage, thus moderate these health disparities. In this instance, multi-method research (involving quantitative and qualitative approaches) would be an invaluable asset for facilitating the design of future interventions, effective to overcome identified barriers faced by low income women accessing health care services.

An Australian population-based survey ${ }^{[73]}$ was distributed by hospitals and home birth practitioners to women six months after childbirth to examine stressful life events, social health issues (e.g. being single, divorced or widowed; having a 
below-average income; not completing year 12; smoking at any stage of pregnancy) and low birth weight. Using regression modeling, one of the findings showed that women reporting three or more social health issues $(18 \%, 768 / 4352)$ were more likely to have a low-birth-weight infant $(<2500$ grams) after controlling for smoking and other socio-demographic covariates. While this illustrates that social variables can influence individuals in the perinatal period (with ongoing implications in child health), it is also highlights areas we can intervene to increase overall population wellbeing.

Women with greater support resources appear to have fewer health risks ${ }^{[74]}$. Social factors have also been shown to play a protective role and moderate the impact of stress on physical health and psychological well-being ${ }^{[75,76]}$, overall helping to increase coping skills, self-esteem, self-control and self-confidence ${ }^{[77]}$. For instance, social support was found to be of benefit during pregnancy as reported by Glazier, Elgar ${ }^{[78]}$ in a study of 2052 Canadian mothers in which higher levels of social support correlated with fewer symptoms of depression and anxiety (typical bivariate correlations $>r=.30$, suggest that approximately $10 \%$ of depression in these mothers was related to poor social support).

With respect to the childbearing period, social resources are especially important for women's health status because of the psychosocial demands of childbearing and parenting ${ }^{[79]}$. Further studies have demonstrated that satisfaction with the social support given by a woman's partner and/or family had significant beneficial effects on the later well-being of the mother and child by reducing the risk of postpartum depression ${ }^{[80,81]}$. Collins, Dunkel-Schetter ${ }^{[82]}$ found social support resources during pregnancy had a substantial, statistically significant correlation between prenatal support quality and depressed mood. Evidence suggests that a lack of social support is a risk factor for postnatal depression, while strong social ties can serve as a buffer ${ }^{[83]}$. Thus social support has good claims for being a priority target of intervention as it regularly predicts a range of indices of women's postnatal health status. The health benefits to be gained are substantial ; in one study researchers found low antenatal support to be a risk factor for postnatal depression ${ }^{[84]}$. The more than three-fold increase in risk clearly suggests that careful assessment of a woman's level of support should be included in all screenings of expectant mothers.

\subsection{Psychological factors associated with perinatal health}

An understanding of the salient factors, as well as the conceptual and empirical underpinnings of 'perinatal mental health' is essential to provide identification, early detection and optimal care. Recognised internationally as a major public health issue, as many as $15 \%$ of childbearing women are likely to develop a new episode of major or minor depression in the interval between conception and the first three postpartum months ${ }^{[85]}$. According to the WHO, depression was the leading cause of disability worldwide and the fourth leading contributor to the global burden of disease (the disability adjusted lives per years) in $2000^{[86]}$. By the year 2020, WHO predicts that depression will be the second largest contributor to the global disability adjusted lives per years for all ages, while currently, depression is already the second largest cause of disability adjusted lives per years for those of reproductive age (15 - 44 years of ages) ${ }^{[86]}$.

As the perinatal period is acknowledged to be a time of heightened stress and a trigger for reduced emotional wellbeing and increased depression and anxiety ${ }^{[87]}$, it has been suggested that symptoms of depression, including appetite change, lowered energy, sleep disturbance and reduced libido, have considerable impact not just on the mother but on the infant ${ }^{[88]}$. Not only depression but also anxiety in pregnancy is harmful to the fetus and contributes to adverse obstetric outcomes, including intrauterine growth impairment of the fetuses and operative deliveries ${ }^{[89,90]}$. There are many social factors that are associated with anxiety in pregnancy, and it has been found to be higher amongst younger, less educated women of low socioeconomic status ${ }^{[91]}$. In addition to social factors, many experiences during pregnancy can generate anxiety, e.g. genetic screening ${ }^{[92]}$.

Risk factors for postnatal depression include poor social support, a personal history of mood disorder, previous psychiatric hospitalisation and anxious or depressed mood during pregnancy which have all been consistently found to be predictive of postnatal depression. With respect to women who have a history of mood disorders, further research is required to 
determine an individual's risk of a relapse in the perinatal period. This will enable clinicians to more precisely estimate risk at the individual level and plan services accordingly.

Another key psychosocial risk factor that has been identified includes a poor relationship between the woman and her partner ${ }^{[93,94]}$. Poor support from a male partner is thought to be amenable to change ${ }^{[95]}$ which suggests that there may be value in developing services in this area for new and expectant fathers.

\subsubsection{Outcomes of antenatal mood disorders}

As many as $18 \%$ of pregnant women are depressed during their pregnancy ${ }^{[85]}$, while Bennett et al. ${ }^{[96]}$ found the incidence of depression to be $7.4 \%, 12.8 \%$ and $12.0 \%$ in the first, second and the third trimester respectively. Numerous studies indicate that high stress and mood disturbances during pregnancy are associated with a variety of negative infant outcomes ${ }^{[97]}$, including key outcomes such as low birth weight, preterm birth ${ }^{[89]}$, and lower Apgar scores. There is substantial literature that attempts to explain the possible mechanism for such associations given the prevalence of poor pregnancy outcomes and their potentially serious long-term consequences ${ }^{[98-100]}$, and evidence is mounting to suggest that compromised fetal development may have effects on health and cognition that stretch through childhood into adulthood ${ }^{[99]}$. Most recently a study identified that a lack of support, poor emotional understanding by the partner, and additional stress subsequent to gynecological disorders were significantly associated with prematurity delivery. Pregnancy-related fears and general anxiety were additional significant predictors for preterm delivery ${ }^{[101]}$. In regards to antenatal interventions to support pregnant women, there is currently no evidence to suggest that interventions are more effective when developed in conjunction with the involvement of other allied health professions e.g. mental health professionals. Further research could review contextual interventions to determine this.

\subsubsection{I mpact of postnatal mood disorders}

Postnatal mood disorders are a common form of maternal morbidity following birth ${ }^{[102]}$. These disorders can range in severity from the mild and transient "baby blues" (experienced by $50 \%$ to $80 \%$ of women) to postpartum psychosis, a major psychiatric condition that affects one to two per 1000 deliveries ${ }^{[103]}$. Amongst these disorders is postnatal depression, a condition affecting around $15 \%$ of women ${ }^{[104]}$, and having potentially serious consequences for maternal, partner and infant well-being and development ${ }^{[105,106]}$. The unique impact of maternal mental illness on the cognitive, emotional, social, and behavioural development of infants has been widely researched ${ }^{[107-109]}$, but more large-scale, multivariate cohort studies are needed if we are to better understand the pathways involved, and thus be in a position to target resources aimed at minimising the developmental delays that can result from maternal postnatal mood disorders.

An Edinburgh Postnatal Depression Scale screening programme in Hong Kong has generated benefits in that it was associated with improved mental health outcomes of postnatal women ${ }^{[110]}$. To apply such a screening program to other Westernised culture, more evidence from experimental studies conducted in a range of settings is needed. Furthermore, the cost effectiveness of such a programme remains to be established.

\section{Conclusion}

Using a public health context, the forgoing review offers insights for optimising maternal and child health outcomes by directing greater attention to potentially modifiable risk factors across the perinatal period. While evidence suggests that Western nations are generally very safe places for childbirth ${ }^{[111-114]}$, the perinatal period is a complex life-altering phenomenon consisting of much more than the safe delivery of a child, but rather influenced by a multitude of biopsychosocial factors as illustrated throughout this paper. Using the ICF framework, the biopsychosocial analysis allowed researchers to identify core indicators and conditions for achieving optimal maternal and child health. Our findings suggest further research is needed across all of the domains of the ICF, but especially studies which involve the evaluation of treatments that have been manualised to ensure treatment fidelity. Clearly, aiming to have significantly higher rates of evidence-based manualised treatments (i.e. assuring programme fidelity) would be a useful next step in 
research across the perinatal period. While factors across the whole of the biopsychosocial spectrum are obviously involved in enhancing maternal and child health, the persisting stream of evidence about the importance of effective social support (including professional, partner and informational support) highlights this area as a priority for both service development and future research, including the assessment of social support which may be included as part of all expectant mothers' screening. Further, while this review has stimulated areas for future research, it also describes the cumulative impact of the various biopsychosocial factors which can influence perinatal outcomes. Such modifiable factors are opportunities for service development, where perinatal health professionals can work collaboratively to educate and facilitate the overall transition to parenthood. The next step forward is to design and evaluate a robust multidisciplinary perinatal intervention (combining timely support and education and facilitating resources) that addresses the biopsychosocial processes and modifiable contextual factors.

\section{References}

[1] Koplan JP, Bond C, Merson MH, Reddy S, Rodriguez MN, Sewankambo NK, et al. Towards a common definition of global health. The Lancet. 2009 June 6; 373(9679):1993-5. http://dx.doi.org/10.1016/S0140-6736(09)60332-9

[2] Lin V, Smith J, Fawkes S. Public Health Practice in Australia: The Organised effort. Australia: Allen \& Unwin; 2007

[3] Almond P. Postnatal depression: A global public health perspective. Perspect Public Health. 2009 September; 129(5): $221-7$. PMid:19788165

[4] Newman LA. The health care system as a social determinant of health: qualitative insights from South Australian maternity consumers. Aust Health Rev. 2009 February; 33(1): 62-71. PMid:19203335 http://dx.doi.org/10.1071/AH090062

[5] Engel CL. The need for a new medical model: A challenge for biomedicine. Science. 1977 Apr 8;196(4286):129-36. PMid:847460 http://dx.doi.org/10.1126/science.847460

[6] World Health Organization. Towards a Common Language for Functioning, Disability and Health - ICF. The International Classification of Functioning, Disability and Health [Internet]. 2002[cited 2012 October 4]. World Health Organization, Geneva. Available from: http://www.who.int/classifications/icf/training/icfbeginnersguide.pdf

[7] Li Z, McNally L, Hilda L, Sullivan EA. Australia’s mothers and babies 2009. Perinatal statistics series no. 25. Cat no. PER 52. Sydney: AIHW National Perinatal Epidemiology and Statistics Unit. Available from: http://stats.oecd.org/Index.aspx?DataSetCode=HEALTH_PROC

[8] Craig PL, Knight J, Webster V, Harris E. Initiation and Duration of Breastfeeding in an Aboriginal Community in South Western Sydney. J Hum Lact. 2011 Aug; 27(3):250-61. PMid:21788654 http://dx.doi.org/10.1177/0890334411402998

[9] Australian Institute of Health and Welfare. A Picture of Australia's Children. Cat. no. PHE58, Canberra, Australia. 2005

[10] Wisner L, Chambers C, Sit D. Postpartum depression: a major public health problem. JAMA. 2006 Dec 6; $296(21): 2616-8$. PMid:17148727 http://dx.doi.org/10.1001/jama.296.21.2616

[11] Australian Institute of Health and Welfare. Experience of perinatal depression: data from the 2010 Australian National Infant Feeding Survey. Information Paper. Canberra: AIHW, 2012.

[12] Jordan J. The relational self: A model of women's development. In: J Mens-Verhulst, Schreurs K, Woertman L, editors. Daughtering and Mothering: Female Subjectivity Reanalysed. London: Routledge; 1993

[13] Schumacher KL, Meleis AI. Transitions: A central concept in nursing. Image J Nurs Sch. 1994; 26(2):119 - 27. http://dx.doi.org/10.1111/j.1547-5069.1994.tb00929.x

[14] Schytt E, Hildingsson I. Physical and emotional self-rated health among Swedish women and men during pregnancy and the first year of parenthood. Sex reprod Healthc. 2011 Apr;2(2):57-64. PMid:21439522 http://dx.doi.org/10.1016/j.srhc.2010.12.003

[15] Lumbiganon P, Laopaiboon M, Gülmezoglu AM, Souza JP, Taneepanichskul S, Ruyan P, et al. Method of delivery and pregnancy outcomes in Asia: the WHO global survey on maternal and perinatal health 2007-08. The Lancet. 2010 February 6; 375(9713): 490-9. http://dx.doi.org/10.1016/S0140-6736(09)61870-5

[16] Kuklina E, Meikle S, Jamieson D, Whiteman M, Barfield W, Hills S, et al. Severe obstetric morbidity in the United States: 19852005. Obstet Gynecol. 2009 Feb; 113(2 Pt 1):293-9. PMid:19155897

[17] Koroukian S. Relative risk of postpartum complications in the Ohio medicaid population: vaginal versus cesarean delivery. Med Care Res Rev. 2004 Jun; 61(2):203-24. PMid:15155052 http://dx.doi.org/10.1177/1077558703260123

[18] Hadar E, Melamed N, Tzadikevitch-Geffen K, Yogev Y. Timing and risk factors of maternal complications of cesarean section. Arch Gynecol Obstet. 2011 Apr; 283(4):735-41. PMid:20354706 http://dx.doi.org/10.1007/s00404-010-1450-0 
[19] Liu S, Heaman M, Joseph KS, Liston RM, Huang L, Sauve R, et al. Risk of Maternal Postpartum Readmission Associated with Mode of Delivery. The American College of Obstetricians and Gynecologists. 2005 Apr;105(4):836-42. PMid:15802414 http://dx.doi.org/10.1097/01.AOG.0000154153.31193.2c

[20] Lydon-Rochelle M, Holt VL, Martin DP, Easterling TR. Association Between Method of Delivery and Maternal Rehospitalization JAMA: The Journal of the American Medical Association. 2000 May 10; 283(18):2411-6. PMid:10815084 http://dx.doi.org/10.1001/jama.283.18.2411

[21] Leth RA, Moller JK, Thomsen RW, Uldbjerg N, Norgaard M. Risk of selected postpartum infections after cesarean section compared with vaginal birth: A five-year cohort study of 32,468 women. Acta Obstet Gynecol Scand. 2009 Sep; 88(9):976-83. PMid:19642043 http://dx.doi.org/10.1080/00016340903147405

[22] Kealy MA, Small R, Liamputtong P. Recovery after caesarean birth: a qualitative study of women's accounts in Victoria, Australia. BMC Pregnancy Childbirth. 2010 Aug 18;10:47. PMid:20718966 http://dx.doi.org/10.1186/1471-2393-10-47

[23] Turnbull D A, Wilkinson C, Yaser A, Carty V, Svigos JM, Robinson JS. Women's role and satisfaction in the decision to have a caesarean section. Med J Aust. 1999 Jun 21; 170(12):580-3. PMid:10416426

[24] Uma R, Libby G, Murphy DJ. Obstetric management of a woman's first delivery and the implications for pelvic floor surgery in later life. BJOG. 2005 Aug; 112(8):1043-6. PMid:16045515 http://dx.doi.org/10.1111/j.1471-0528.2005.00641.x

[25] Schytt E, Lindermark G, Waldernstrom U. Physical symptoms after childbirth: Prevalence and associations with self-rated health. BJOG. 2005 Feb; 112(2):210-7. PMid:15663586 http://dx.doi.org/10.1111/j.1471-0528.2004.00319.x

[26] Bick D, MacArthur C. Attendance, content and relevance of the six week postnatal examination. Midwifery. 1995 Jun;11(2):69-73. http://dx.doi.org/10.1016/0266-6138(95)90069-1

[27] Kahn RS, Zuckerman B, Bauchner H, Homer CJ, Wise PH. Women's health after pregnancy and child outcomes at age 3 years: A prospective cohort study. Am J Public Health.. 2002 Aug; 92(8):1312-8. PMid:12144990 http://dx.doi.org/10.2105/AJPH.92.8.1312

[28] Turner C, Boyle F, O'Rourke P. Mothers' health post-partum and their pattens of seeking vaccination for their infants. Int J Nurs Pract. 2003 Apr; 9(2):120-6. PMid:12694481 http://dx.doi.org/10.1046/j.1322-7114.2003.00410.x

[29] Cheng C-Y, Li Q. Integrative review of research on general health status and prevalence of common physical health conditions of women after childbirth. Womens Health Issues. 2008 Jul-Aug;18(4):267-80. PMid:18468922 http://dx.doi.org/10.1016/j.whi.2008.02.004

[30] Kline CR, Martin DP, Deyo RA. Health consequences of pregnancy and childbirth as perceived by women and clinicians. Obstet Gynecol. 1998 Nov;92(5):842-8. http://dx.doi.org/10.1016/S0029-7844(98)00251-8

[31] Cheater FM, Castleden CM. Epidemiology and classification of urinary incontinence. Baillieres Best Pract Res Clin Obstet Gynaecol. 2000 Apr;14(2):183-205. http://dx.doi.org/10.1053/beog.1999.0071

[32] Doran CM, Chiarelli P, Cockburn J. Economic costs of urinary incontinence in community dwelling Australian women. Med J Aust. 2001;174(9): 456-8. PMid:11386591

[33] Borders N. After the Afterbirth: A Critical Review of Postpartum Health Relative to Method of Delivery. J Midwifery Womens Health. 2006 Jul-Aug;51(4): 242-8. PMid:16814217 http://dx.doi.org/10.1016/j.jmwh.2005.10.014

[34] Albers LL. Health Problems after Childbirth. J Midwifery Womens Health. 2000 January-February; 45(1): 55-7. http://dx.doi.org/10.1016/S1526-9523(99)00003-3

[35] Declercq E, Sakala C, Corry MP, Applebaum S, Risher P. Listening to mothers: Report of the first national U.S. survey of women's childbearing experiences. New York: Maternity Center Association; 2002.

[36] Mørkved S, Bø K. Effect of pelvic floor muscle training during pregnancy and after childbirth on prevention and treatment of urinary incontinence: a systematic review. Br J Sports Med. 2013 January 30. PMid:23365417 http://dx.doi.org/10.1136/bjsports-2012-091758

[37] McCourt C, Page L. Report on the Evaluation of One-to-One Midwifery. London: Centre for Midwifery Practice, Thames Valley University, Hammersmith Hospitals NHS Trust, 1996.

[38] Albert H, Godskesen M, Westergaard J. Prognosis in four syndromes of pregnancy-related pelvic pain. Acta Obstet Gynecol Scand. 2001 June; 80(6): 505-10. PMid:11380285 http://dx.doi.org/10.1080/j.1600-0412.2001.080006505.x

[39] Noren L, Ostgaard S, Johansson G, Ostgaard HC. Lumbar back and posterior pelvic pain during pregnancy: a 3-year follow-up. Eur Spine J. 2002(11): 267-71. PMid:12107796

[40] Council of Australian Governments. Protecting Children is Everyone’s Business, National Framework for Protecting Australia's Children 2009-2020. Canberra: Commonwealth of Australia. 2009.

[41] Brown S, Lumley J. Maternal health after childbirth: results of an Australian population based survey. Br J Obstet Gynaecol. 1998 Feb; 105(2):156-61. PMid:9501779 
[42] Chein L-Y, Tai C-J, Hwang F-M, Huang C-M. Postpartum physical symptoms and depressive symptomology at 1 month and 1 year after delivery: A longtitudinal survey. Int J Nurs Stud. 2009 Sep; 46(9):1201-8. PMid:19278680 http://dx.doi.org/10.1016/j.ijnurstu.2009.02.007

[43] Ansara D, Cohen MM, Gallop R, Kung R, Schei B. Predictors of women's physical health problems after childbirth. J Psychosom Obstet Gynaecol. 2005 Jun;26(2):115-25. PMid:16050537 http://dx.doi.org/10.1080/01443610400023064

[44] Brown S, Lumley JM, McDonald EA, Krastev AH. Maternal health study: a prospective cohort study of nulliparous women recruited in early pregnancy. BMC Pregnancy Childbirth. 2006 April 11; (6): 12-24. PMid:16608507 http://dx.doi.org/10.1186/1471-2393-6-12

[45] Williams A, Herron-Marx S, Knibb R. The prevalence of enduring postnatal perineal morbidity and its relationship to type of birth and birth risk factors. J Clin Nurs. 2007 Mar; 16(3):549-61. PMid:17335531 http://dx.doi.org/10.1111/j.1365-2702.2006.01593.x

[46] Gjerdingen DK, Froberg DG, Chaloner KM, McGevern PM. Changes in women's physical health during the first postpartum year. Arch Fam Med. 1993 Mar; 2(3):277-83. PMid:8252148 http://dx.doi.org/10.1001/archfami.2.3.277

[47] Saurel-Cubizolles MJ, Romito P, Lelong N, Ancel P-Y. Women's health after childbirth: a longitudinal study in France and Italy. BJOG. 2000; Oct;107(10):1202-9. PMid:11028569 http://dx.doi.org/10.1111/j.1471-0528.2000.tb11608.x

[48] Brown S, Lumley J. Physical health problems after childbirth and maternal depression at six to seven months postpartum. BJOG. 2000 Oct;107(10):1194-201. PMid:11028568 http://dx.doi.org/10.1111/j.1471-0528.2000.tb11607.x

[49] Gutke A, Josefsson A, Oberg B. Pelvic Girdle Pain and Lumbar Pain in Relation to Postpartum Depressive Symptoms. SPINE. 2007 Jun 1; 32(13):1430-6. PMid:17545912 http://dx.doi.org/10.1097/BRS.0b013e318060a673

[50] Webb DA, Bloch JR, Coyne JC, Chung EK, Bennett IM, Culhane JF. Postpartum Physical Symptoms in New Mothers: Their Relationship to Functional Limitations and Emotional Well-being. BIRTH. 2008 Sep; 35(3):179-87. PMid:18844643 http://dx.doi.org/10.1111/j.1523-536X.2008.00238.x

[51] Prince M, Patel V, Saxena S, Mario M, Maselko J, Phillips MR, et al. No health without mental health. Lancet. 2007 September; 370(9590): 859-77. http://dx.doi.org/10.1016/S0140-6736(07)61238-0

[52] beyondblue. Clinical Practice Guidelines for Depression and Related Disorders - Anxiety, Bipolar Disorder, and Puerpal Psychosis - in the Perinatal Period. beyondblue: Melboune; 2010

[53] Parry BL, Sorenson D, Meliska CJ, Basavaraj N, Zirpoli GG, Gamst A, et al. Hormonal basis of mood and postpartum disorders. Curr Womens Health Rep. 2003 Jun; 3(3):230-5. PMid:12734034

[54] Ressler KJ, Nemeroff CB. Role of serotonergic and noradrenergic systems in the pathophysiology of depression and anxiety disorders. Depress Anxiety. 2000; 12 Suppl 1:2-19. http://dx.doi.org/10.1002/1520-6394(2000)12:1+<2::AID-DA2>3.0.CO;2-4

[55] Gazal M, Motta LS, Wiener CD, Fernandes JC, Quevedo L, Jansen K, et al. Brain-Derived Neurotrophic Factor in Post-Partum Depressive Mothers. Neurochem Res. 2012 Mar;37(3):583-7. PMid:22102172 http://dx.doi.org/10.1007/s11064-011-0647-3

[56] Sandman C, Davis E, Buss C, Glynn L. Exposure to Prenatal Psychobiological Stress Exerts Programming Influences on the Mother and Her Fetus. Neuroendocrinology. 2012; 95(1): 8-21. PMid:21494029 http://dx.doi.org/10.1159/000327017

[57] Nierop A, Bratsikas A, Klinkenberg A, Nater UM, Zimmermann R, Ehlert U. Prolonged salivary cortisol recovery in second-trimester pregnancy women and attenuated salivary Amylase Responses to psychosocail stress in human pregnancy. $\mathrm{J}$ Clin Endocrinol Metab. 2006 Apr; 91(4):1329-35. PMid:16434458 http://dx.doi.org/10.1210/jc.2005-1816

[58] Hendrick V, Altshuler LL, Suri R. Hormonal Changes in the Postpartum and Implications for Postpartum Depression. Psychosomatics. 1998 Mar-Apr; 39(2):93-101. http://dx.doi.org/10.1016/S0033-3182(98)71355-6

[59] Leung BM, Kaplan BJ. Perinatal depression: prevalence, risks, and the nutrition link--a review of the literature. J Am Diet Assoc. 2009 Sep;109(9):1566-75. PMid:19699836 http://dx.doi.org/10.1016/j.jada.2009.06.368

[60] Picciano MF. Pregnancy and lactation: Physiological adjustments, nutritional requirements and the role of dietary supplements. J Nutr. 2003 June 1; 133(6): 1997S-2002S. PMid:12771353

[61] Bodnar LM, Wisner KL. Nutrition and depression: implications for improving mental health among childbearing-aged women. Biol Psychiatry. 2005 Nov 1;58(9):679-85. PMid:16040007 http://dx.doi.org/10.1016/j.biopsych.2005.05.009

[62] Alpert JE, Mischoulon D, Nierenberg AA, Fava M. Nutrition and depression (Focus on folate). Nutrition. 2000 Jul-Aug;16(7-8):544-6. http://dx.doi.org/10.1016/S0899-9007(00)00327-0

[63] Beard JL, Hendricks MK, Perez EM, Murray-Kolb LE, Berg A, Vernon-Feagans L, et al. Maternal Iron Deficiency Anemia Affects Postpartum Emotions and Cognition. J Nutr. 2005 February 1; 135(2): 267-72. PMid:15671224

[64] Barger M. Maternal Nutrition and Perinatal Outcomes. J Midwifery Womens Health. 2010 Nov-Dec; 55(6):502-11 PMid:20974412 http://dx.doi.org/10.1016/j.jmwh.2010.02.017

[65] Marmot M, R G Wilkinson (eds). Social Determinants of Health. New York: Oxford University Press; 1999. 
[66] Pattenden S, Dolk H, Vrijheid M. Inequalities in low birth weight: parental social class, area deprivation, and "lone mother" status. J Epidemiol Community Health. 1999 June; 53(6): 355-8. PMid:10396482 http://dx.doi.org/10.1136/jech.53.6.355

[67] Moser K, Li L, Power C. Social inequalities in low birth weight in England and Wales: trends and implications for furture population health. J Epidemiol Community Health. 2003 September; 57(9): 687-91. PMid:12933774 http://dx.doi.org/10.1136/jech.57.9.687

[68] Gissler M, Rahjonen O, Arntzen A, Cnattingius S, Andersen A-MN, Hemminki E. Trends in socioeconomic differences in Finnish perinatal health 1991 - 2006. J Epidemiol Community Health. 2009 Jun;63(6):420-5. PMid:19211588 http://dx.doi.org/10.1136/jech.2008.079921

[69] Tyano S, Keren M. Single parenthood: its impact on parenting the infant. In: Tyano S, Keren M, Herrman H, Cox J, editors. Parenthood and Mental Health: A Bridge between Infant and Adult Psychiatry: John Wiley \& Sons; 2010. http://dx.doi.org/10.1002/9780470660683.ch3

[70] Hosseini SM, Biglan MW, Larkby C, Brooks MM, Gorin MB, Day NL. Trait anxiety in pregnant women predicts offspring birth outcomes. Paediatr Perinat Epidemiol. 2009 Nov; 23(6):557-66. PMid:19840292 http://dx.doi.org/10.1111/j.1365-3016.2009.01065.x

[71] Zhu P, Tao F, Hao J, Sun T, Jiang X. Prenatal life events stress: implications for preterm birth and infant birthweight. Am J Obstet Gynecol. 2010 Jul; 203(1):34.e1-8. http://dx.doi: 10.1016/j.ajog.2010.02.023

[72] Lobel M, Cannella DL, Graham JE, DeVincent C, Schneider J, Meyer BA. Pregnancy-Specific Stress, Prenatal Health Behaviours, and Birth Outcomes. Health Psychol. 2008 Sep; 27(5):604-15. PMid:18823187 http://dx.doi.org/10.1037/a0013242

[73] Brown S, Yelland J, Sutherland G, Baghurst P, Robinson J. Stressful events, social health issues and low birthweight in an Australian population-based birth cohort: challenges and opportunities in antenatal care. BMC Public Health 2011; (11): 196-208. PMid:21450106 http://dx.doi.org/10.1186/1471-2458-11-196

[74] Hung C-H. Predictors of Postpartum Women's Health Status. J Nurs Scholarsh. 2004;36(4):345-51. PMid:15636415 http://dx.doi.org/10.1111/j.1547-5069.2004.04062.x

[75] Razurel C, Bruchon-Schweitzer M, Dupanloup A, Irion O, Epiney M. Stressful events, social support and coping strategies of primparous women during the postpartum period: a qalitative study. Midwifery. 2011; 27(2): 237-42. PMid:19783333 http://dx.doi.org/10.1016/j.midw.2009.06.005

[76] Sarason BR, Sarason IG. Social Support: an Interactional View. New York: Wiley; 1990.

[77] Leahy-Warren P, McCarthy G. Maternal parental self-efficacy in the postpartum period. Midwifery. 2011; 27(6): 802-10. PMid:20888092 http://dx.doi.org/10.1016/j.midw.2010.07.008

[78] Glazier RH, Elgar FJ, Goel V, Holzapfel S. Stress, social support, and emotional distress in a community sample of pregnant women. J Psychosom Obstet Gynaecol. 2004 Sep-Dec; 25(3-4): 247-55. PMid:15715023 http://dx.doi.org/10.1080/01674820400024406

[79] Vaux A. Social Support: Theory, Research, and Intervention. New York: Praeger; 1988.

[80] Tarkka M-T, Paunonen M. Social support and its impact on mothers' experiences of childbirth. J Adv Nurs. 1996 January; 23(1):70-5. PMid:8708226 http://dx.doi.org/10.1111/j.1365-2648.1996.tb03137.x

[81] Terry DJ, Mayocchi L, Hynes GJ. Depressive Symptomology in New Mothers: A Stress and Coping Perspective. J Abnorm Psychol. 1996 May; 105(2):220-31. PMid:8723003 http://dx.doi.org/10.1037/0021-843X.105.2.220

[82] Collins NL, Dunkel-Schetter C, Lobel M, Scrimshaw SCM. Social Support in Pregnany: Psychosocial Correlates of Birth Outcomes and Postpartum Depression. J Pers Soc Psychol. 1993 December; 65(6):1243-58. PMid:8295121 http://dx.doi.org/10.1037/0022-3514.65.6.1243

[83] Webster J, Linnane JW, Dibley LM, Hinson JK, Starrenburg SE, Roberts JA. Measuring Social Support in Pregnancy: Can it be Simple and Meaningful? BIRTH. 2000 Jun; 27(2):97-101. PMid:11251486 http://dx.doi.org/10.1046/j.1523-536x.2000.00097.x

[84] Xie R-H, He G, Koszycki D, Walker M, Wen SW. Prenatal Social Support, Postnatal Social Support, and Postpartum Depression. Ann Epidemiol. 2009 Sep; 19(9):637-43. PMid:19443240 http://dx.doi.org/10.1016/j.annepidem.2009.03.008

[85] Gavin NI, Gaynes BN, Lohr KN, Meltzer-Brody S, Gartlehner G, Swinson T. Perinatal depression: a systematic review of prevalence and incidence. Obstet Gynecol. 2005 Nov; 106(5 Pt 1):1071-83. PMid:16260528 http://dx.doi.org/10.1097/01.AOG.0000183597.31630.db

[86] World Health Organization. Mental Health - Depression. Fact Sheet [Internet]. 2010[cited 2011 April 14]. Available from: http://www.who.int/mental_health/management/depression/definition/en/index1.html.

[87] Matthey S, Barnett B, Howie P, Kavanagh DJ. Diagnosing postpartum depression in mohters and fathers: whatever happened to anxiety? J Affect Disord. 2003 Apr; 74(2):139-47. http://dx.doi.org/10.1016/S0165-0327(02)00012-5

[88] Llewellyn AM, Stowe ZN, Nemeroff CB. Depression during pregnancy and the puerperium. Journal of Clinical Psychiatry. 1997; 58 Suppl 15:26-32. PMid:9427874 
[89] Alder J, Fink N, Bitzer J, Hösli I, Holzgreve W. Depression and anxiety during pregnancy: A risk factor for obstetric, fetal and neonatal outcome? A critical review of the literature. J Matern Fetal Neonatal Med. 2007 Mar; 20(3):189-209. PMid:17437220 http://dx.doi.org/10.1080/14767050701209560

[90] Qiao Y-X, Wang J, Li J, Ablat A. The prevalence and related risk factors of anxiety and depression symptoms among Chinese pregnant women in Shanghai. Aust N Z J Obstet Gynaecol. 2009 Apr; 49(2):185-90. PMid:19432608 http://dx.doi.org/10.1111/j.1479-828X.2009.00966.x

[91] Glazer G. Anxiety levels and concerns among pregnant women. Research Nursing Health. 1980 Sep; 3(3):107-113. PMid:6904055 http://dx.doi.org/10.1002/nur.4770030305

[92] Green J. Prenatal screening and diagnosis: Some psychological and social issues. Br J Obstet Gynaecol. 1990 Dec; 97(12):1074-6. PMid:2279016 http://dx.doi.org/10.1111/j.1471-0528.1990.tb02492.x

[93] Milgrom J, Gemmill AW, Bilszta JL, Hayes B, Barnett B, Brooks J, et al. Antenatal risk factors for postnatal depression: a large prospective study. J Affect Disord. 2008 May; 108(1-2):147-57. PMid:18067974 http://dx.doi.org/10.1016/j.jad.2007.10.014

[94] Beck C. Predictors of Postpartum depression: an update. Nurs Res. 2001 September-October; 50(5):275-85. PMid:11570712 http://dx.doi.org/10.1097/00006199-200109000-00004

[95] Highet N, Gemmill A, Milgrom J. Depression in the Perinatal Period: Awareness, Attitudes and Knowledge in the Australian Population. Australian and New Zealand Journal of Psychiatry. 2011 Mar; 45(3):223-31. PMid:21438748 http://dx.doi.org/10.3109/00048674.2010.547842

[96] Bennett HA, Einarson A, Taddio A, Koren G, Einarson TR. Prevalence of depression during pregnancy: systematic review. Obstet Gynecol. 2004 Apr;103(4):698-709. PMid:15051562 http://dx.doi.org/10.1097/01.AOG.0000116689.75396.5f

[97] Bonari L, Bennett H, Einarson A, Koren G. Risks of untreated depression during pregnancy. Can Fam Physician. 2004 January; 50: 37-9. PMid:14761100

[98] Austin MP, Leader L. Maternal stress and obstetric and infant outcomes: epidemiological findings and neuroendocrine mechanisms. Aust N Z J Obstet Gynaecol. 2000 Aug; 40(3):331-7. PMid:11065043 http://dx.doi.org/10.1111/j.1479-828X.2000.tb03344.x

[99] Hobel CJ, Goldstein A, Barrett E. Psychosocial Stress and Pregnancy Outcome. Clin Obstet Gynecol. 2008(51): 333-48. PMid:18463464 http://dx.doi.org/10.1097/GRF.0b013e31816f2709

[100] Huizink AC, De-Medina PG, Mulder EJ, Visser GH, Buitelaar JK. Coping in normal pregnancy. Ann Behav Med. 2002 Spring;24(2):132-40. PMid:12054318 http://dx.doi.org/10.1207/S15324796ABM2402_10

[101] Rauchfuss M, Maier B. Biopsychosocial predictors of preterm delivery. J Perinat Med. 2011 Sep; 39(5):515-21. PMid:21867452 http://dx.doi.org/10.1515/jpm.2011.067

[102] Stocky A, Lynch J. Acute psychatric disturbance in pregnancy and the puerperium. Baillieres Best Pract Res Clin Obstet Gynaecol. 2000 Feb;14(1):73-87. http://dx.doi.org/10.1053/beog.1999.0064

[103] Doucet S, Jones I, Letourneau N, Dennis C-L, Blackmore ER. Interventions for the prevention and treatment of postpartum psychosis: a systematic review. Arch Womens Ment Health. 2011 Apr; 14(2):89-98. PMid:21128087 http://dx.doi.org/10.1007/s00737-010-0199-6

[104] Leahy-Warren P, McCarthy G. Postnatal Depression: Prevalence, Mothers' Perspectives, and Treatments. Arch Psychiatric Nur. 2007 Apr; 21(2):91-100. PMid:17397691 http://dx.doi.org/10.1016/j.apnu.2006.10.006

[105] Milgrom J, Ericksen J, McCarthy R, Gemmill AW. Stressful impact of depression on early mother-infant relations. Stress and Health. 2006 October; 22(4): 229-38. http://dx.doi.org/10.1002/smi.1101

[106] Milgrom J, Westleya DT, Gemmill AW. The mediating role of maternal responsiveness in some longer term effects of postnatal depression on infant development. Infant Behavior and Development. 2004 December; 27(4):443-54. http://dx.doi.org/10.1016/j.infbeh.2004.03.003.

[107] Tyano S, Keren M, Herrman H, Cox J, Barton J. Maternal Postnatal Mental Disorder: How Does It Affect the Young Child? In: Cox J, Barton J, editors. Parenthood and Mental Health: A Bridge between infant and adult psychiatry: John Wiley \& Sons, Ltd; 2010. http://dx.doi.org/10.1002/9780470660683.

[108] Manning C, Gregoire A. Effects of parental mental illness on children. Psychiatry. 2009 January; 8(1):7-9. http://dx.doi.org/10.1016/j.mppsy.2008.10.012.

[109] Waxier E, Thelen K, Muzik M. Maternal Perinatal Depression - Impact on Infant and Child Development. European Obstetrics \& Gynaecology. 2011 March 3; 7(1):25-31.

[110] Leung SS, Leung C, Lam TH, Hung SF, Chan R, Yeung T, et al. Outcome of a postnatal depression screening programme using the Edinburgh Postnatal Depression Scale: a randomized controlled trial. J Public Health (Oxf). 2011 June; 33(2):292-301. PMid:20884642 http://dx.doi.org/10.1093/pubmed/fdq075 
[111] Australian Government Department of Health and Ageing. Improving Maternity Services in Australia: The report of the maternity services review. In: Department of Health and Ageing, editor. Barton, ACT: Commonwealth of Australia; 2009. p. 1-68.

[112] Bernis L, Sherratt D, Abouzahr C, Lerberghe WV. Skilled attendants for pregnancy, childbirth and postnatal care. Br Med Bull. 2003; 67(1): 39-57. PMid:14711753 http://dx.doi.org/10.1093/bmb/ldg017

[113] Rasch V. Maternal death and the millennium development goals. Danish Medical Bulletin. 2007; 54(2):167-9. PMid:17521538

[114] World Health Organization. Maternal mortality in 2005 : estimates developed by WHO, UNICEF, UNFPA, and the World Bank[Internet]. 2007[cited 2012 December 5]. Avaliable from: http://www.who.int/whosis/mme_2005.pdf. 